\title{
An Understanding Demographic Bonus and Its Implication among Teenagers in Deli Serdang District
}

\author{
Heru Santosa ${ }^{1}$, Erna Mutiara $^{2}$, Juanita $^{3}$ \\ ${ }^{1,2,3}$ Faculty of Public Health, University of Sumatera Utara, Indonesia \\ heru_php2@yahoo.com \\ erna3eusu.ac.id \\ joean_ita@yahoo.com
}

\begin{abstract}
Population structure in Deli Serdang District showed that the productive age (15-64 years) was greater than nonproductive age (children and elderly). This condition is called demographic bonus, which is predicted will occur in 2020.

This study tried to describe the understanding of demographic bonus and its implication among teenagers in four (4) subdistricts in Deli Serdang District which were near Kuala Namu International Airport. The samples were teenagers aged 15-24 years and data were collected by interviewing them.

The result showed that only $\mathbf{1 2 . 6} \%$ of the teenagers knew about the definition of demographic bonus. About $64,6 \%$ of teenagers agreed that in connection with the demographic bonus, then employment for teenagers was very important. The fact that many residents were young but accompanied by a lack of access to education, skills and employment were a worrying combination according to $87.6 \%$ teenagers. Only $58.6 \%$ of teenagers felt the benefits as an economic opportunity of the presence of the airport for their areas.

Meanwhile, 32.6\% of teenagers stated that there was no benefits due to the presence of the airport. Eventhough many of teenagers $(\mathbf{7 4 . 7 \%})$ stated that with the economic opportunity of the presence of the airport creating jobs in this area, but many teenagers were unemployment. The Deli Serdang local government should give information about demographic bonus and its implication to the teenagers. Otherwise, they will lose the chance to enjoy the demographic bonus which offered a significant opportunity for the Deli Serdang's economic development if teenagers' work skills and aptitude were developed as soon as possible.
\end{abstract}

Keywords- - demographic bonus, employment, teenagers, Deli Serdang, economic development

\section{INTRODUCTION}

One other strategic issues related to the development of the population in Sumatera Utara province and district/city is a change in the composition of the population, particularly by age. With the trend of changes in the composition of the population by age in the past, is expected to reach the stage of windows of opportunity in 2030.

Moreover, Indonesia is currently in a transition period of the productive age population structure, expecting to get a bonus of demography (demographic dividend) in the period of 2020-2030. This demographic dividend provides huge benefit potential in terms of development and economy, i.e. when the composition of productive age population (15-64 years) reaches a maximum point, compared to non-productive age (0-14 years old and over 65 years). This demographic dividend can provide economic benefits, because the total savings of the productive population will be greater so as to spur investment and economic growth. This fact indicates the increasing importance of employment in order to take advantage of population number of the productive age [1].

This will only happen if the management of the quantity of the population, especially fertility, done right. If not, then the stage will be missed and Sumatera Utara province will lose the momentum to accelerate accelerating achievement of national development goals. Stage windows of opportunity are marked with numbers dependence of the lowest in the development of changes in the composition of the population according to age.

A population's changing age structure can, under certain conditions, provide a powerful stimulus to economic growth and family welfare. The current demographic condition in Indonesia are ripe for taking advantage of such a "demographic bonus" or "dempgraphic dividend"; in fact, favourable condition have been in place for some time but the window of apportunity will start ti close after another decade or so. The demographic devident refers to the accelerated economic growth that begins with changes in the age structure of 
cauntry's population as its transitions from high to low birth and death rates [2], [3].

A second characteristic which inevitably changes as a population goes through its demographic transition is the population age structure, that is, the relative proportion of total population in each age group. Since people of different ages have different consumption needs and engage in different kinds of productive activities a changing age structure can have massive implications for economic growth and family welfare [4]. Figure 1 gives a schematic representation of how the population growth rate and the share of the population in the working ages vary in relation to one another as the population goes through its demographic transition.

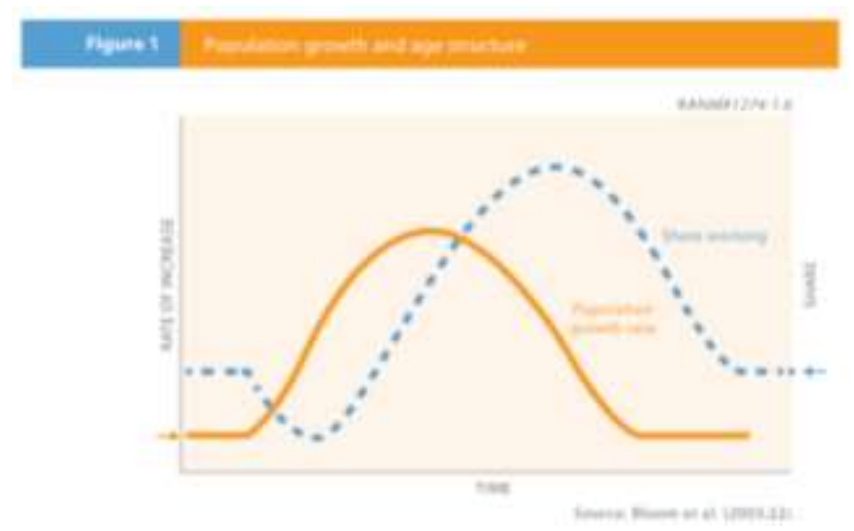

Fig 1.Population anda age structure

Demographic Bonus is a bonus that is enjoyed by a country as a result of the large proportion of the productive population (age range 15-64 years) in the evolution of population. In years 2020 to 2030 Indonesia experienced a demographic bonus is due to the demographic transition process that develops since a few years ago accelerated with the success of family planning programs to lower fertility rates and improved quality of healthcare as well as the success of other development programs. However, this productive age when quality is not even going to be borne by the state. Standard demographic transition theory holds that transition takes place concurrently with socioeconomic development.

The condition is characterized by a large number of productive age population, the declining number of children aged population, and the increasing number of senior citizens. This stage is an opportunity that only comes once and must be responded to with an adequate policy in order to turn into a demographic bonus opportunity. If this stage occurred and no intervention is appropriate, then the event will turn into a disaster (disaster). There are three important aspects in the development of population policy.

First, internally, the dynamics of population enters a crucial stage marked by the change in demographic conditions "under-estimated". The condition is apparent from the changes the birth rate and population growth are likely to not move forward (stagnant). Apart from differences in the interpretation of these circumstances, this condition needs to be observed and anticipated with appropriate population policies.

Second, the development of population policy has not fully become an integral part of development policy. This is not consistent with the results of the ICPD (International Conference on Population and Development) in 1994 in Cairo which mandates that, the integration of population policies into national development policies.

Third, at the same time population dynamics are heading for phase windows of opportunity that comes only once and will provide an opportunity to obtain demographic bonus. These three things are the reason why we need a draft text of the study as Grand Design Implications of Demographic and Economic Development Bonus-Creative-Based Advanced Responsive Local. Grand Design is necessary to be a way for the formulation of population policies and programs in the future is also expected to be in line with the Master Plan for the Acceleration and Expansion of Indonesian Economic Development (MP3EI) and the Master Plan for the Acceleration and Expansion of Indonesia Poverty Reduction (MP3KI).

Grand Design of Implications Bonus Demographic and Economic Development Responsive Specific Local-Based Creative will be conducted in Deli Serdang. Deli Serdang are chosen based on several considerations: First, the district is a buffer zone of Medan as the center of the capital. Secondly, the area will evolve since their prospective new airport Kualanamu. Third, most of the population is marginal with lower economic level and the underprivileged. Kempat, many potential young school dropouts who are not 
productive as a consequence of the demographic bonus.

Theoretically, demographic bonus is the difference between the rate of growth of working age population and total population. The positive differences offered a one-time window of opportunity for any ountry or region to make use for economic growth [5].

Research purposes are assess the implications of the demographic bonus in Deli Serdang, a case study in around the international airport of Kuala Namo. Assess the implications of development opportunities of the population as a demographic bonus. To develop the specific potential of local resources. Responsive economic developmentbased creative locale specific. Intervention and responsive economic development-based creative locale specific.

\section{II.METHODS AND MATERIALS}

This study is a combination of qualitative and quantitative research. Qualitative research is used to dig deeper into the factors that lead to children dropping out of school, what to do after dropping out of school, the type of work that is suitable for school dropouts and designing a model of economic development based creative responsive local specific to confront demographic bonus.

Quantitative research is used to get an overview of the characteristics of children out of school in Deli Serdang and factors related to the incidence of dropping out of school and work status of school children. For qualitative research, which became informants for the relevant agencies and quantitative research is all households that have children graduated from junior high/high school and are unemployed and live in the area around the international airport of Kuala Namo. Samples are head of the household and the children graduated from junior high/high school and unemployed.

\section{RESULTS AND DISCUSSION}

Based on source data from BPS-Statistics of Deli Serdang Regency 2016, according to the latest, 2010 Population Census Deli Serdang's population was about 1,790,431 persons include population that had no permanent residence and it made Deli Serdang on the second position in the largest number of population in Sumatera Utara after Medan [6]. Population growth rate in the period 2010-2015 based on final number of population census was 2.08 percent. Number of Deli Serdang's population estimated in June 2015 was 2,029,308 persons with population density 812 persons per square kilometers. Still in the same year, the number of household was 475,365. Most of household lived in urban area 360.628 of household and 114,37 of household lived in rural area. And average of population per household was about 4 persons, even though population growth rate in period 2010-2015 was 2.08 percent. Percentage of male population with sex ratio 101.3 , it means that number of males populations more than females or in every 100 females there was 101 males.

Deli Serdang population structure in 2014 shows that the productive age (15-64 years) amounted to 1,309,256 inhabitants and 675342 inhabitants nonproductive age [7]. This situation will be very beneficial when it can be utilized as best as possible. The demographic bonus in Deli Serdang impact on the availability of abundant labor but labor absorption is very low will increase the number of unemployed.

The result showed that only $12.6 \%$ of the teenagers knew about the definition of demographic bonus. About $64,6 \%$ of teenagers agreed that in connection with the demographic bonus, then employment for teenagers was very important. The fact that many residents were young but accompanied by a lack of access to education, skills and employment were a worrying combination according to $87.6 \%$ teenagers. Only $58.6 \%$ of teenagers felt the benefits as an economic opportunity of the presence of the airport for their areas.

Meanwhile, $32.6 \%$ of teenagers stated that there was no benefits due to the presence of the airport. Eventhough many of teenagers $(74.7 \%)$ stated that with the economic opportunity of the presence of the airport creating jobs in this area, but many teenagers were unemployment. 


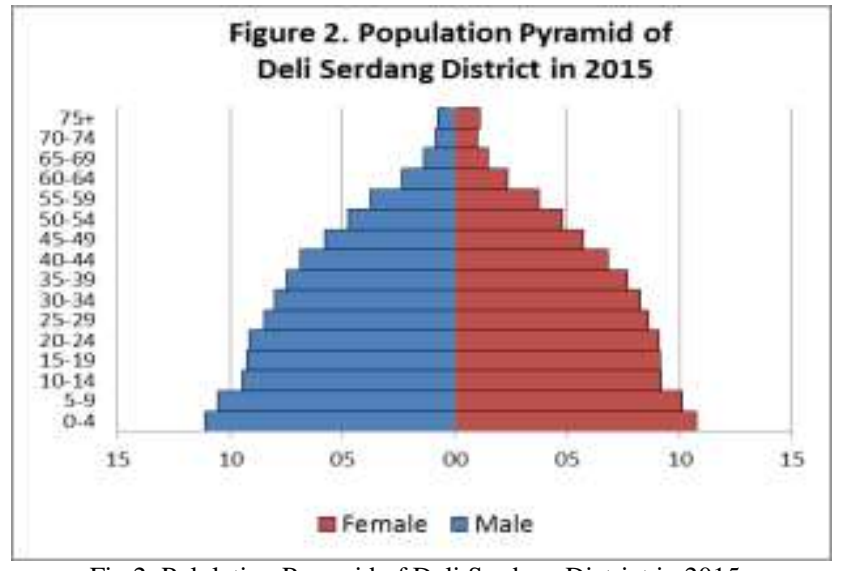

Fig 2. Polulation Pyramid of Deli Serdang District in 2015

Attrition percentage rise in Deli Serdang 2012/2013 academic year is below 1\%, both for the primary level, secondary and upper secondary/ vocational. This illustrates that the Government of Deli Serdang have achieved success in the field of education, namely by zeroing figures for the number of students who drop out of school. But what about the employment of children out of school? Of the total labor force of 898033 people, about $93 \%$ are already working, but of the work is still much lower level of education. (premery school) of $28 \%$, so that labor productivity is still low.

Further, when traced teen unemployment rate in the area of this study, based on the perception of respondents were entering numbers. The unemployment rate was also no different from informants recognition of Women Empowerment, Child Protection and Family Planning which is about $10-20 \%$.

Table 1 shows that the cause of unemployment in the study area are multifactorial. The cause of them is due to the displacement of labor from agriculture to industry and while idle. The second cause is due to the waiting period to stop the work of the old and looking for a new job better. Third, due to changes in economic structure, which is an agrarian economy turned into a system that demands changes in the industrial structure of skills that can support the industry, so that idle while to adjust. Next, due to termination of employment, because many job seekers while employment opportunities are limited, because education is not fulfilled in accordance with the needs and the latter is due to low skills.
TABLE I

PERCEPTION ABOUTH CAUSE UNEMPLOYMENT $(\mathrm{N}=283$ )

\begin{tabular}{|l|l|c|c|}
\hline No. & Cause Unemployment & Number & $\%$ \\
\hline 1 & Displacement sector & 22 & 7,8 \\
\hline 2 & Stop work & 26 & 9,2 \\
\hline 3 & Economic changes & 22 & 7,8 \\
\hline 4 & Work termination & 46 & 16,3 \\
\hline 5 & Limited employment & 147 & 51,9 \\
\hline 6 & Low education & 139 & 49,1 \\
\hline 7 & Low-skiiled & 130 & 45,9 \\
\hline
\end{tabular}

Further search of this study also indicated that based on the perception of respondents regions will have the prospect to develop even realize there is still unemployed teenagers. The main reason is because of the perception that the region is a region adjacent of Kuala Namo International Airport. In general, respondents believe that this area will be well and thrive, from all respondents interviewed turned out to be $76.4 \%$ stated that he was confident.

This study also found that the opportunities possible to be developed in the area of study, namely regarding economic opportunities and business activities, opportunities are opening up employment, employment opportunities to trade, development opportunities services, business opportunities craft souvenir and gift, the opportunity of buying and selling and the opportunity to easing unemployment.

The processed data indicate the presence of opportunities regarding its proximity to the International Airport hub of Kuala Namo, then in the study area should be prepared to evolve creating business opportunities so that the economy is capable of absorbing and eliminating the teenage unemployment. In harmony with the perception of respondents, then chances these opportunities can only be the development of the agricultural sector, such as hydroponic farming, trade, food business, printing business and of course the development of the services sector.

TABLE II

PERCEPTION ON RESPONSIVE ECONOMIC DEVELOPMENT RESPONSIVE CREATIVE LOCALLY-BASED SPECIFIC (N: 283)

\begin{tabular}{|l|l|c|c|}
\hline No. & $\begin{array}{l}\text { Perceptian developed } \\
\text { opportunities }\end{array}$ & Total & $\%$ \\
\hline 1 & Agriculture & 116 & 41,0 \\
2 & Trade & 221 & 78,1 \\
3 & Food business & 198 & 69,9 \\
4 & Printing business & 64 & 22,6 \\
5 & Service & 112 & 39,6 \\
\hline
\end{tabular}




\section{Conclusion ANd ReCommendations}

In general the whole area experienced a "demographic bonus" is the increasing number of productive age population compared to the nonproductive age population in the period 2020-2030. Productive age is a phase of life that are in the working age and childbearing age, from 15-64 years.

This demographic dividend can be an advantage or a acaman. Demographic dividend can be keuntugan if the population aged 15-64 years were qualified and productive, otherwise the demographic bonus to be a threat if the population is in the age of 15-64 years it did not have sufficient knowledge and skills so that even a burden on other residents.

The results of this study recommend that meet the demographic bonus in 2020-2030 then the conceptual need to do is to prepare quality of education and quality of human resources in the present. The concept of economic development based on specific responsive and creative local is their alternative.

\section{REFERENCES}

[1] Edie Toet Hendratno and Rachma Fitriati, 2015. The Study of Indonesia's Readines to Cope With Demographic Bonus: A Review of Population Law. "Journal of Indonesian Economy and Business". Vol.30, No. 3:195-219.

[2] Gribble, James N, and Jason Bremner, 2012. "Achieving a demographic dividend." Population Bulletin 67, 2. Washington DC: Population Reference Bureau.

[3] Adrian Hayes and Diahhadi Setyonaluri, 2015. Taking Advantage of The Demographic Devidend in Indonesia (A Brief Introduction to Theory and Practice). Jakarta: UNFPA, Indonesia.

[4] Bloom et al. 2003. Bloom, David E, David Canning and Jaypee Sevilla, 2003. The Demographic Dividend: A New Perspective on the Economic Consequences of Population Change Santa Monica, CA: RAND.

[5] Jamal Abdul Nasir and M.H Tahir, 2011. "Prolonging the Native Demographic Bonus: An Emprical Evidence". International Journal of Business and Social Science, Vol.2 No.7:107.

[6] BPS-Statistics of Deli Serdang Regency, 2016. Deli Serdang Regency in Figures 2016. Lubuk Pakam: BPS-Statistics of Deli Serdang Regency.

[7] BPS-Statistics of Sumatera Utara Province, 2015. Sumatera Utara in Figures 2014. Medan : BPS-Statistics of Sumatera Utara Province. 